\title{
IL-2, IFN- $\gamma$ and anti-HBs based Immune Responses to Hepatitis B Vaccine in Type 2 Diabetic Patients
}

\author{
ASHESH KUMAR CHOWDHURY, ${ }^{1}$ SUJAL KUMAR BOKSHI, ${ }^{1}$ ZEENAT FARZANA RAHMAN, ${ }^{1}$ MD. ABU TAHER, ${ }^{1}$ \\ SUBHAGATA CHOUDHURY2
}

\begin{abstract}
:
Background: The immune status is usually hampered in patients of diabetes mellitus. The global pandemic of diabetes principally involves type 2 diabetes. In diabetic patients higher prevalence of hepatitis $B$ virus infection is also noted that leads to more severe complications. This study was conducted to determine the immune responses to hepatitis $B$ vaccine in type 2 diabetic patients.
\end{abstract}

Methods: In this study 33 diabetic patients were included as experimental group and 34 non diabetic healthy persons were included as control group. All the participants were vaccinated with hepatitis $B$ vaccine following 0, I, 6 months schedule. The vaccine responses in diabetic and non diabetic group were compared depending on seromarkers (anti-HBs titer, IL-2 and IFN- $\gamma$ ) following vaccination.

Results: The mean value of anti-HBs titer was lower in diabetic group $(357.81 \mathrm{~m} / \mathrm{U} / \mathrm{m} /)$ than non diabetic group $(621.24 \mathrm{mlU} / \mathrm{ml})$ but the difference was not significant $(p>0.05)$, the mean value of IFN- $\gamma$ was lower in diabetic group $(0.1480 \mathrm{IU} / \mathrm{ml})$ than non diabetic group $(0.2788 \mathrm{IU} / \mathrm{ml})$ and here the difference was significant $(p<0.05)$, the mean value of serum IL-2 level was also lower in diabetic group $(0.26 \mathrm{I} \mathrm{IIU/ml)}$ than non diabetic group $(0.369 \mathrm{l} \mathrm{IU} / \mathrm{ml})$ but the difference was not significant $(p>0.05)$.

Conclusion: The study revealed no statistically significant variation in anti-HBs and IL-2 but a diminished IFN- $\gamma$ level as the immune response in diabetic patients after $\mathrm{HBV}$ infection.

Key words: Anti-HBs; IL-2; IFN- $\gamma$; Hepatitis B Vaccine; Type 2 Diabetes.

\section{Introduction:}

Both diabetes mellitus and hepatitis B virus infection are life threatening condition. They are being considered as great burden for global public health and their frequencies are dramatically increasing day by day all over the world. In 2000 , the prevalence of diabetes for all age groups worldwide was estimated as $2.8 \%$ and the number of diabetic people was 171 million. In 2030, the prevalence of diabetes mellitus may rise from $2.8 \%$ to $4.4 \%$ if the current flow continues and then the number of diabetic patients will increase from 171 million to 366 million. ${ }^{1}$ The global pandemic principally involves type 2 diabetes (85\%-95\%) to which several factor contribute, including obesity, sedentary life style, greater longevity, unsatisfactory diet and increasing urbanization. ${ }^{2,3}$ On the other hand, across the world, about two billion people have been infected with hepatitis B virus and about 350 million live with chronic infection. An estimated 600,000 people die each year due to the acute or chronic consequences

Department of Immunology; ${ }^{1}$ Director Laboratory Sevices; ${ }^{2}$ Bangladesh Institute of Research and Rehabilitation in Diabetes, Endocrine and Metabolic disorder (BIRDEM), 122- Kazi Nazrul Islam Avenue, Shahbag, Dhaka-1000

Corresponding address: Dr. Ashesh Kumar Chowdhury, Associate Professor, Department of Immunology, BRIDEM, 122- Kazi Nazrul Islam Avenue, Shahbag, Dhaka-1000, Bangladesh. Tel: +880-1920175781; Email: ashesh66@gmail.com. of hepatitis B infection. Hepatitis B is endemic in Asia, where $8 \%$ to $10 \%$ of the adult population is chronically infected. In the Middle East and Indian sub-continent, an estimated $2 \%$ to $5 \%$ of the general population is chronically infected. ${ }^{4}$ The prevalence of hepatitis B virus infection is higher in diabetic patients than in the healthy people. ${ }^{5}$ Diabetes mellitus worsens the hepatic condition of hepatitis patients and increase the risk of complication. ${ }^{6}$ Diabetes mellitus is related to increase the risk of developing chronic liver disease (CLD) and hepatocellular carcinoma (HCC). It is also associated with more advanced lesion and poor outcome in patients with hepatocellular carcinoma. ${ }^{7,8}$ Diabetes mellitus accelerates liver fibrosis and the incidence of bacterial infection in cirrhotic patients which are associated with increasing mortality. In hepatic disease metabolic homeostasis of glucose is impaired. As a result, blood glucose level may rise (hepatogenous diabetes) that makes the total diabetic condition very severe. ${ }^{6}$ An easy and reliable way of preventing the infection is vaccination with hepatitis $\mathrm{B}$ vaccine but diabetic patients face abnormality in different stages of immunity. ${ }^{9} 10,11$ From the administration of antigen to development of immunity, vaccine is to pass through some vital steps to which several factors contribute such as cellular factor (APC, T cell, B cell) and chemical factor (MHC, Transcription factor, Cytokine) etc. IL-2 and IFN- $\gamma$ are the 
two important cytokines that play a vital role in different stages of immune response. IL-2 activates variety of cell of immune system including helper T cells, cytotoxic T cells, B cells, macrophages, natural killer cells. During immune response T cell secrets IL-2 that in combination with other cytokines induces B cell differentiation and immunoglobulin secretion. ${ }^{12}$ IL-2 associating with the high affinity receptor of $\mathrm{T}$ cells (autocrine) induces the activated naive $\mathrm{T}$ cell to proliferate and differentiate. ${ }^{13}$ The major functions of INF- $\gamma$ are activation of monocyte or macrophage, induction of class I and II MHC antigens, modulation of immunoglobulin system, modulation of cytokine synthesis, induction of differentiation in myelomonocytic cells, inhibition of cell growth, inhibitory action on the multiplication of virus and some other intercellular infectious agents. INF- $\gamma$ has a regulatory role in the control of immunoglobulin isotypes produced by activated B cells. INF- $\gamma$ shows positive effect especially in the secretion of $\operatorname{IgG} 2 \mathrm{a} .{ }^{14}$ In different research works an increased serum level of IL- 2 and IFN- $\gamma$ was observed following infection and vaccination. This observation indicates the relationship of IL- 2 and IFN- $\gamma$ with immune response. ${ }^{15,16}$ Therefore, if serum anti-HBs, IL-2 and IFN- $\gamma$ in type 2 diabetic and non diabetic individuals following hepatitis $\mathrm{B}$ vaccination can be analyzed and compared, it may give a comparative account of immunological response against hepatitis B vaccine between type 2 diabetic and non diabetic individuals. This study was undertaken with the idea that it may provide more immunological insight into hepatitis B infection in type 2 diabetic patients in a clinical setting.

\section{Methods and Materials:}

Type 2 diabetic patients were included as experimental sample, who carried fasting plasma glucose level as $\geq 7.0$ $\mathrm{mmol} \mathrm{l}^{-1}$ or $\geq 126 \mathrm{mg} \mathrm{d} \mathrm{l}^{-1} 17,18$. Total participants were 67 , out of which 33 were diabetic and 34 were non diabetic. The samples were selected by non probability purposive sampling. All participants were informed about the study (procedure, advantage, disadvantage etc) before taking written consent and the research protocol was approved by the Ethical Review Committee (ERC) of the Diabetic Association of Bangladesh (BADAS). The study was carried out in the Department of Immunology, Bangladesh Institute of Research and Rehabilitation in Diabetes, Endocrine and Metabolic disorder (BIRDEM), 122- Kazi Nazrul Islam Avenue, Shahbag, Dhaka-1000. The duration of the study was one year (November, 2009-October, 2010). The participants were assessed pathologically by some common laboratory investigation such as serum bilirubin, serum creatinine and SGPT. Serum HBsAg, serum anti-
HBs and serum anti-HBc were assayed for all participants to exclude post hepatitis B vaccinated cases, current hepatitis B infected or cured cases. The participants were vaccinated with recombinant hepatitis B vaccine following 0, 1, 6 month schedule. Serum was collected for three times after completing vaccination at $7^{\text {th }}$ day, $14^{\text {th }}$ day and $28^{\text {th }}$ day of last vaccination. Blood was collected aseptically, centrifuged for 10 minutes at $1000 \mathrm{~g}$, the serum was collected immediately and preserved at $<-70^{0} \mathrm{C}$ temperature. IFN- $\gamma$ was assayed in $14^{\text {th }}$ day's serum, IL-2 was assayed in $7^{\text {th }}$ day's serum and anti-HBs were assayed in $28^{\text {th }}$ day's serum. Anti-HBs titer $\geq 10 \mathrm{mIU} / \mathrm{mL}$ is considered as seroprotective titer (responder for vaccine) and titer $<10 \mathrm{mIU} / \mathrm{mL}$ is considered as non seroprotective titer (non responder for vaccine) ${ }^{19,20}$. The seromarkers (anti-HBs, IFN- $\gamma$ \& IL-2) were compared between the experimental and control groups. The level of significance was expressed as $p$ value $<0.05$. IFN- $\gamma$ and IL-2 were assayed by Enzyme Linked Immunosorbant Assay (ELISA) technique (Kit; DRG, USA). Anti-HBs was assayed under Chemiluminescence Enzyme Immunoassay (CLEIA) technique (Kit; IMMULITE, UK) and anti-HBc was assayed by Microparticle Enzyme Immunoassay (MEIA) technique (Kit; ABBOTT, USA) following the basic principle of competitive/blocking CLEIA procedure. HBsAg was assayed by a rapid screening test device that works under Immuno-Chromatography (ICT) Technique (Kit; EXCEL, USA).

\section{Results:}

The mean age of diabetic (experimental) group was 51.76 years and non diabetic (control) group was 50.74 years. Among the 33 diabetic patients 26 (78.79\%) was male and $7(21.21 \%)$ was female, among the 34 non diabetic people $26(76.47 \%)$ was male and $8(23.53 \%)$ was female. The mean values of serum bilirubin were calculated as $0.527 \mathrm{mg} / \mathrm{dl}$ and $0.489 \mathrm{mg} / \mathrm{dl}$ for diabetic and non diabetic groups respectively. The mean values of serum ALT was calculated as 29.67U/L and $28.90 \mathrm{U} / \mathrm{L}$ for diabetic and non diabetic groups respectively. The calculated mean values of serum creatinine were $0.791 \mathrm{mg} / \mathrm{dl}$ for diabetic group and $0.742 \mathrm{mg} / \mathrm{dl}$ for non diabetic group. The mean fasting plasma glucose levels were noted as $9.656 \mathrm{mmol} / \mathrm{L}$ and $5.056 \mathrm{mmol} / \mathrm{L}$ in diabetic and non diabetic group respectively (table-1). It is remarkable that the participants of the study were selected only among them who were HBsAg and anti-HBs negative (non detectable). Anti-HBc was tested in the serum of nonresponder and all anti-HBc tests were negative. 
Seroprotective titer (anti-HBs titer $\geq 10 \mathrm{mIU} / \mathrm{mL}$ ) was developed in 61(91\%) samples out of 67, the rest 6 samples were non responder (anti-HBs titer $<10 \mathrm{mIU} / \mathrm{mL}$ ). In diabetic group the protective response was noted in $30(90.91 \%)$ patients out of 33 and in non diabetic group the protective response was noted in 31(91.18\%) individuals out of 34 (Table-II).

The mean values of anti-HBs titer were $357.80 \mathrm{mIU} / \mathrm{mL}$ for diabetic group and $621.24 \mathrm{mIU} / \mathrm{mL}$ for non diabetic group after vaccination. The difference between two mean value looked bigger in naked eye but the $\mathrm{p}$ value was identified as $>0.05$ and $Z$ value was identified as 1.61 . The mean value of IFN- $\gamma$ was calculated $0.1480 \mathrm{IU} / \mathrm{ml}$ in diabetic group and $0.2788 \mathrm{IU} / \mathrm{ml}$. The difference of the mean value of IFN- $\gamma$ was remarkable because here $p$ value was calculated as $<0.05$ and $\mathrm{Z}$ value was calculated as 2.15 . The mean values of serum IL-2 were calculated as $0.2611 \mathrm{IU} / \mathrm{ml}$ and $0.3691 \mathrm{IU} / \mathrm{ml}$ in diabetic and non diabetic groups respectively. Here, there is also a great difference between the two mean values but the analyzed $p$ value was found as $>0.05$ and the $Z$ value was found as 1.80 (Table-III).

Table-I

Physical and biochemical markers with their comparison between diabetic and non diabetic group.

\begin{tabular}{lccc}
\hline Parameters & $\begin{array}{c}\text { Diabetic group } \\
(\mathrm{N}=33)\end{array}$ & $\begin{array}{c}\text { Non diabetic group } \\
(\mathrm{N}=34)\end{array}$ & $\begin{array}{c}\text { P } \\
\text { value }\end{array}$ \\
\hline Age (years) & $51.76 \pm 08.80$ & $50.74 \pm 10.22$ & $>0.05$ \\
Gender & M-26 (78.79\%) & M-26 (76.74\%) & $>0.05$ \\
& FM-7 (21.21\%) & FM- $8(23.53 \%)$ & $>0.05$ \\
Serum bilirubin $(\mathrm{mg} / \mathrm{dl})$ & $0.527 \pm 0.139$ & $0.489 \pm 0.140$ & $>0.05$ \\
SGPT /ALT $(\mathrm{U} / \mathrm{L})$ & $29.67 \pm 7.421$ & $28.90 \pm 6.685$ & $>0.05$ \\
Serum creatinine $(\mathrm{mg} / \mathrm{dl})$ & $0.791 \pm 0.159$ & $0.742 \pm 0.128$ & $<0.0001$ \\
Fasting plasma glucose $(\mathrm{mmol} / \mathrm{L})$ & $9.656 \pm 2.938$ & $5.056 \pm 1.158$ & \\
\hline
\end{tabular}

* Values were expressed as (mean $\pm \mathrm{SD})$.

$* \mathrm{~N} \rightarrow$ Number, $\mathrm{SD} \rightarrow$ Standard Deviation, $\mathrm{M} \rightarrow$ Male, $\mathrm{FM} \rightarrow$ Female.

Table-II

The number and percentage of seroprotective titer in diabetic and non diabetic group fallowing hepatitis $B$ vaccination.

\begin{tabular}{|c|c|c|c|c|c|c|}
\hline & \multicolumn{2}{|c|}{$\begin{array}{c}\text { Diabetic group } \\
\text { (Total 33) }\end{array}$} & \multicolumn{2}{|c|}{$\begin{array}{c}\text { Non diabetic } \\
\text { group (Total 34) }\end{array}$} & \multirow[t]{2}{*}{$\begin{array}{c}Z \\
\text { value }\end{array}$} & \multirow[t]{2}{*}{$\begin{array}{c}\mathrm{P} \\
\text { Value }\end{array}$} \\
\hline & Number & $\%$ & Number & $\%$ & & \\
\hline $\begin{array}{l}\text { seroprotective titer } \\
\text { / responder (titere+10 mIU/mL) }\end{array}$ & 30 & 90.91 & 31 & 91.18 & 0.04 & $>0.05$ \\
\hline $\begin{array}{l}\text { non seroprotective } \\
\text { titer/ non responder } \\
\text { (titer }<10 \mathrm{mIU} / \mathrm{mL} \text { ) }\end{array}$ & 3 & 9.09 & 3 & 8.82 & & \\
\hline
\end{tabular}

*Comparison of percentage was done by proportion $\mathrm{Z}$ test.

Table-III

The summarized value of post-vaccination anti-HBs titer, IFN- $\gamma, I L-2$ in diabetic and non diabetic group.

\begin{tabular}{lcccc}
\hline Parameters & \multicolumn{2}{c}{ Mean value } & Z value & P value \\
\cline { 2 - 5 } & Diabetic group & Non diabetic group & & \\
\hline anti-HBs titer & $357.80 \mathrm{mIU} / \mathrm{mL}$ & $621.24 \mathrm{mIU} / \mathrm{mL}$ & 1.61 & $>0.05$ \\
IFN- $\gamma$ & $0.1480 \mathrm{IU} / \mathrm{ml}$ & $0.2788 \mathrm{IU} / \mathrm{ml}$ & 2.15 & $<0.05$ \\
IL-2 & $0.2611 \mathrm{IU} / \mathrm{ml})$ & $0.2611 \mathrm{IU} / \mathrm{ml})$ & 1.80 & $>0.05$ \\
\hline
\end{tabular}

*Comparison of percentage was done by proportion $\mathrm{Z}$ test. 


\section{Discussion:}

The experimental and control group differed from each other on the basis of presence or absence of diabetes. No significant variation was observed on the parameters of age, sex, serum bilirubin, ALT and serum creatinine between the two groups $(p>0.05)$. None of the participants was a case of acute hepatitis B viral infection (HBsAg negative) or none of them was a case of post hepatitis B infection or post hepatitis B vaccination (non detectable anti-HBs titer). In the study the hepatitis B vaccination response fulfilled the gold standard vaccine response criteria, because after completing vaccination seroprotective titer was developed in $91 \%$ sample (anti-HBs titer $>10 \mathrm{mIU} / \mathrm{mL}$ ). ${ }^{19}$ Seroprotective titer was similar to both the diabetic $(90.91 \%)$ and non diabetic $(91.18 \%)$ groups ( $>0.05)$. The mean values of serum antiHBs titer, IFN- $\gamma$ and IL-2 were remarkably lower in diabetic group than in non diabetic group but only in case of seromarker IFN- $\gamma$, the difference was found significant $(\mathrm{p}<0.05)$ and in case of other two seromarkers (anti-HBs titer \& IL-2 level) the differences were not found significant $(>0.05)$.

\section{Acknowledgement:}

Sujal Kumar Bokshi contributed to design and write the research work. Zeenat Farzana Rahman and Md. Abu Taher contributed to perform experiments.

\section{Conflict of interest:}

There was no conflict of interest.

Abbreviations: ALT; Alanine Aminotransferase, Anti-HBc; Antibody to hepatitis B core antigen, Anti-HBs; Antibody to hepatitis B surface antigen, APC; Antigen presenting cell, IFN; Interferon, Ig; Immunoglobulin, IL; Interleukin, IU; International unit, MHC; Major Histocompatibility complex, SGPT; serum glutamic pyruvic transaminase

\section{References:}

1. Sarah W, Gojka R, Anders G, Richard S, Hilary K. Global Prevalence of Diabetes. Diabetes Care. 2004;27:1047-53.

2. IDF (International Diabetic Federation). Latest Diabetic Figures paint grim global picture 2009; Retrieved on 15 Jan 2010 from http://www.idf.org/latest-diabetes-figures-paintgrim-global-picture.

3. Frier BM, Fisher M. Diabetes Mellitus. In: Nicholas AB, Nicki RC, Brain RW and John AAH eds. Davidson's Principles and Practice of Medicine. 20 ${ }^{\text {th }}$ Edn. New Delhi: Elsevier. 2006:808-47.

4. WHO. Hepatitis B, Fact sheet No 204 2008; Retrieved on 7 Jun 2010 from http://www.who.int/mediacentre/factsheets/ fs204/en/

5. Demir M, Seren E, Gokturk S, Ozturk NA, Kulaksizoglu S, Ylmaz U. The prevalence of occult hepatitis B virus infection in type 2 diabetes mellitus patients. European Journal of Gastroenterology and Hepatology. 2008; 20: 668-73.
6. Diego G, Joel OJ, Jose AG, Hector M. Liver cirrhosis and diabetes: Risk factors, pathophysiology, clinical implications and management. World Journal of Gastroenterology. 2009; $15: 280-88$.

7. Davila JA, Morgan RO, Shaib Y, McGlynn KA, El-Serag HB. Disease increase the risk of hepatocellular carcinoma in the United Status: a population based case control study. Gut. 2005;54:533-39.

8. Deepak NA, Nikhil DP, Praful MK. Impact of diabetes mellitus on outcome of HCC. Annals of Hepatology. 2008; 7:148-51.

9. Jadwiga MA, Dinesh K, Miroslaw S, Mariusz K, Shaul GM. Polymorphoneuclear Leukocytes in Non-Insulin-depended Diabetes Mellitus: Abnormalities in Metabolism and Function. Annals Internal Medicine. 1996;123:919-24.

10. Delamaire M, Maugendre D, Moreno M, Le Goff MC, Allannic H, Genetet B. Impaired Leucocyte Functions in Diabetic Patients. Diabetic Medicine. 1997;14:29-34.

11. Alba-Loureiro TC, Munhoz CD, Martins JO, Cerchiaro GA, Scavone C, Curi R, Sannomiya P. Neutrophil function and metabolism in individuals with diabetes mellitus. Brazilian Journal of Medical and Biological Research. 2007;40:103744.

12. Peter JD and Ivan MR. Interleukin 2. In: Ivan MR and Peter JD eds. Encyclopeadia of Immunology. London: Academic Press Limited. 1992:903-6.

13. Thomas JK, Richard AG, Barbara AO. Kuby Immunology, $6^{\text {th }}$ Edn. New York: WH Freeman and Company. 2007:20462,481-85.

14. Jan V, Junming L. Interferon- ${ }^{3}$. In: Ivan MR and Peter JD eds. Encyclopeadia of Immunology. London: Academic Press Limited. 1992:892-95.

15. Mathias WH, Hans JW, Andrea K, Holger K. Cytokine Production in a Whole-Blood Assay after Epstein - Barr virus Infection In Vivo. Clinical and Diagnostic Laboratory Immunology. 1995;2:209-13.

16. Dao-Zhen X, Ke-Lin H, Kai Z, Li-feng X, Nan S, ZhengHong Y, Yu-MW. Vaccination with recombinant HBsAgHBIG complex in healthy adults. Vaccine. 2005;23:265864.

17. WHO. Definition, Diagnosis and Classification of Diabetes Mellitus and its Complications 1999; Retrieved on 10 Jan 2010 from http://www.staff.ncl.ac.uk/philip.home/ who_dmg.pdf

18. WHO. Diabetes, Fact sheet No 312 2009; Retrieved on 16 Jan 2010 from http://www.who.int/mediacentre/factsheets/ fs $312 / \mathrm{en} /$

19. Niyi A. Hepatitis B vaccination in prison. Bulletin of the World Health Organization. 2002;80:596-674.

20. Nahid R, Vajiheh G, Hadi S. Comparison of immune response to hepatitis $\mathrm{B}$ vaccine between term and preterm infants at birth. Iranian Journal of Clinical Infection Disease. 2006;1:11-14. 